\title{
When the Home Becomes a Shrine: Public Prayers in Private Houses among the Ottoman Jews
}

\author{
Dotan Arad
}

Prayer* is a human phenomenon with a dual nature: on the one hand it is an intimate experience, a private meeting between an individual and God. On the other hand it is a collective event - a gathering of the entire community, to sing and pray together. Every religion has to deal with this tension between the two facets of prayer.

Every kind of prayer has its own place. Intimate prayer is usually performed in a private space, inside the walls of the home. Collective prayer, by contrast, is performed in a public place: in Jewish practice, this occurs mainly in the synagogue, but sometimes in other public spaces. For example, in a time of a drought, says the Mishna (the earliest codex of oral Jewish law, edited around $220 \mathrm{CE}$ ), prayer must be performed in the town square. ${ }^{1}$

The separation between public space - the synagogue - and private space the home - can be somewhat blurred. A person can pray alone in the synagogue, but a congregation can also pray in a private house. In this article, I will discuss communal prayers in private houses among the Jews in the Ottoman Empire. What were the circumstances for this phenomenon? And what were its implications?

\section{Private Prayer and Communal Prayer in Judaism}

The Bible is full of examples of figures engaged in intimate prayer, including Abraham, Moses, Hannah, and David. ${ }^{2}$ A touching biblical representation of private prayer in a private space is the supplication of King Hezekiah, who was

* I want to thank Prof. Yaron Ben-Naeh for his comments.

Heb. (throughout the essay) means that the original article was written in Hebrew. I gave the English translation of the title as appeared in the front page, if exists.

1 Mishna Ta'anit 2:1.

2 For bibliography on prayer in the biblical period, see Tabory J., Jewish Prayer and the Yearly Cycle - A List of Articles [Kiryat Sefer, Supplement to Volume 64] (Jerusalem: 1992-1993) 64-65. See also Reif S.C., Judaism and Hebrew Prayer (Cambridge: 1993) 22-52.

(C) DOTAN ARAD, 2019 | DOI:10.1163/9789004375888_004

This is an open access chapter distributed under the terms of the prevailing CC-BY-NC-ND License at the time of publication. 
sick and heard from the prophet that he was going to die. Lying on his bed, he prayed and asked for his life: 'Then Hezekiah turned his face to the wall, and prayed unto the Lord [...] And Hezekiah wept sore.. ${ }^{3}$ However, when the sages of the Mishnah and the Talmud came to shape rabbinic Judaism, they gave clear priority to communal prayer. ${ }^{4}$ Many sermons in rabbinic literature praise the value of collective prayer. Moreover, according to Jewish law, there are several parts of prayer that can only be recited in the presence of ten men who are above the age of thirteen. The following texts are the most important in Jewish prayer: the Kaddish, the Kedushah, the calling 'bless the Lord, the blessed one', and reading from the Torah scroll.

The sages gave clear priority to reciting prayer in the synagogue. The Talmud says: אין תפילתו של אדם נשמעת אלא בבית הכנסת ('A man's prayer is heard [by God] only in the synagogue'). ${ }^{5}$ The ideal prayer, therefore, according to Jewish law, is one recited by a gathering of ten adult males in a synagogue. Maimonides (1138-1204) included those conditions in Mishneh Torah, one of the central codices of Halacha (Jewish law), which was written in Egypt in the twelfth century:

Communal prayer is always heard. Even when there are transgressors among [the congregation], the Holy One, blessed be He, does not reject group prayer. Therefore, a person should include himself in the community and should not pray alone whenever he is able to pray with the community. One should always spend the early morning and evening [hours] in the synagogue, for prayer will not be heard at all times except [when recited] in the synagogue. Anyone who has a synagogue in his city and does not pray [together] with the congregation in it is called a bad neighbour. ${ }^{6}$

3 Isaiah $38: 2-3$.

4 See, for example, Millgram A.E., Jewish Worship (Philadelphia: 1971) 29-32.

5 Babylonian Talmud, Berakhot 6a.

6 Maimonides, Mishne Torah, Laws of Prayer 8:1. Nevertheless, some pious groups acknowledged the legitimacy of private prayer, and even gave it, in some circumstances, priority over public prayer. See for example Russ-Fishbane's description of the pious Jewish circle in Egypt in the twelfth and thirteenth centuries: 'Among the most intriguing developments of Egyptian pietism is the value attached to individual prayer over and above that of communal prayer in the synagogue', Russ-Fishbane E., Judaism, Sufism, and the Pietists of Medieval Egypt (Oxford: 2015) 109; see also his discussion ibid. 108-122. 


\section{2 Communal Prayer in Private Homes: the Case of Ottoman Jewry}

Synagogues in private ownership were very common among the Jews of the Ottoman Empire. The existence of such synagogues is well documented from all over the Empire. ${ }^{7}$ What was the background for this phenomenon?

Ottoman Jewry in the sixteenth and seventeenth centuries was a multicultural society. The Jewish population was divided into natives and immigrants. The native Jews were composed of two main groups: Romaniotes, Greek speakers, who lived in the areas which had previously belonged to the Byzantine Empire, ${ }^{8}$ and Musta'ribs, Arabic speakers, who lived in the areas which had previously belonged to the Mamluk state. ${ }^{9}$ Both groups contained Rabbinic Jews and Karaite Jews (Rabbinic Jews, or Rabbanites, accepted both the Bible and the Oral law. Karaite Jews accepted only the Bible as legal source). Immigrants made up the second element in Jewish society. This period was characterized by continual Jewish immigration to this region, mainly from the Iberian Peninsula, but also from other lands, like Germany, Italy and North Africa.

7 See for example: R. Jacob Berav, She'elot u-Teshuvot (Venice, Andrea Morisoni: 1663) §5 [Famagusta]; R. Joseph Karo, Avqat Rokhel (Salonica, Mordechai, David and Nahman Israelicha: 1791) §122 [Damascus]; R. Mordechai ha-Levi, Darke No'am: She'elot u-Teshuvot (Venice, Vincenzo and Aluise Bragadin: 1697), Even ha-'Ezer §16 [Alexandria]; R. Hayim Benveniste, Ba'e Haye, Hoshen Mishpat (Salonica, Mordechai, David and Nahman Israelicha: 1788-1791) I, §34 [Izmir]; R. Abraham ha-Levi, Ginat Veradim (Istanbul, Jonah b. Jacob of Zaloshitz [Działoszyce]: 1715-1717), Yoreh Déah \#3,1 [Hebron].

8 On the Romaniotes, see Bowman S.B., "Survival in Decline: Romaniote Jewry post-1204", in Bonfil R. - Irshai O. - Stroumsa G.G. - Talgam R. (eds.),Jews in Byzantium:Dialectics of Minority and Majority Cultures (Leiden - Boston: 2012) 101-132; Hollender E., "Mahzor Romania and the Judeo-Greek Hymn Ěvas ó xúpıs: Introduction, Critical Edition, and Commentary", Revue des Études Juives 170 (2011) 117-171; Rozen M., A History of the Jewish Community in Istanbul: The Formative Years, 1453-1566 (Leiden - Boston: 2002) 45, 47, 55-60, 64-77.

9 On the Musta'ribs, see Rozen M., "The Position of the Musta'rabs in the Inter-Community Relationships in Eretz Israel from the 15th Century to the End of the 17th Century", Cathedra 17 (1980) 73-101 (Heb.); Hacker J.R., "On the Character of the Cairo Mustaarib Community Leadership at the End of the Sixteenth Century", in. Hacker J.R. - Harel Y. (eds.), The Scepter Shall not Depart from Judah: Leadership, Rabbinate and Community in Jewish History, Studies Presented to Professor Simon Schwarzfuchs (Jerusalem: 2011) 89-100 (Heb.); Arad D., The Musta'rib Jews in Syria, Palestine and Egypt, 1330-1700, Ph.D. dissertation (Hebrew University of Jerusalem: 2013) (Heb.); Arad D., “'A Clearly Distinguished Community': The Musta'ribs in Damascus in the Sixteenth Century", in Harel Y. (ed.), The Jews of Syria: History, Culture and Identity (Jerusalem: 2015) 95-130 (Heb.); Arad D., "Welfare and Charity in a SixteenthCentury Jewish Community in Egypt: A Study of Genizah Documents", Al-Masāq:Journal of the Medieval Mediterranean 29 (2017) 258-272. 
The various immigrant groups tried to preserve their separate identities by founding independent frameworks, which were called Qahal ('congregation, community' in Hebrew). Every Qahal had its own leadership and its own institutions. ${ }^{10}$ The main institution in the communal life of the Qahal was the synagogue..1 It was not just a place of worship, but was also a social centre. All the public activities of the Qahal were held in it. Discussions of the communal court, deliberations of the leaders, communal meetings, all took place within the synagogue. The centrality of the synagogue in the social life of the Qahal is reflected in the fact that in Ladino, the Judeo-Spanish dialect, the word 'Kal', i.e. Qahal, has two meanings: 'a communal framework' and 'a synagogue'.

Most of the synagogues which were established by the Jewish immigrants in the Ottoman Empire were not located in separate public buildings, but rather in houses in a crowded yard, sharing common walls and a common yard with many neighbours, both Jews and non-Jews. ${ }^{12}$ Some of the houses were

10 On the Qahal and its institutions, see Shaw S.J., The Jews of the Ottoman Empire and the Turkish Republic (London: 1992) 48-77; Hacker J.R., "The Sephardim in the Ottoman Empire in the Sixteenth Century", in Beinart H. (ed.), Moreshet Sepharad: The Sephardi Legacy (Jerusalem: 1992) vol. 2, 118-125; Barnai J., "The Development of Community Organizational Structure: The Case of Izmir", in Levy A. (ed.), Jews, Turks, Ottomans (Syracuse: 2002) 35-51, 296-300; Ben-Naeh Y., Jews in the Realm of the Sultans: Ottoman Jewish Society in the Seventeenth Century (Tübingen: 2008) 163-217.

11 On the synagogues in the Ottoman Empire in the sixteenth and seventeenth centuries, see Hovav Y., Demuto ha-Hevratit ve-ha-Irgunit shel bet ha-Keneset be-Anatolyia vu-vaBalqan, 1550-1650, MA Dissertation (Hebrew University of Jerusalem: 1987); Goldman I.M., The Life and Times of Rabbi David Ibn Abi Zimra (New York: 1970) 102-106; Shaw, The Jews of the Ottoman Empire 66-71; Ben-Naeh, Jews in the Realm of the Sultans 218-236. For an architectural description of the synagogues in the Islamic lands, see Cassuto D., "Synagogues in the Islamic World", in Encyclopedia of Jews in the Islamic World (Leiden Boston: 2010), IV, 423-432. On the material culture of the Synagogues, mainly in Turkey, see Juhasz E., "Synagogues", in Juhasz E. (ed.), Sefardi Jews in the Ottoman Empire: Aspects of Material Culture (Jerusalem: 1990) 36-59.

12 On communal prayers in private houses among the Ottoman Jews, see Cohen A., Jewish Life under Islam:Jerusalem in the Sixteenth Century (Cambridge, Mass.: 1984) 84-86; Hovav, Demuto ha-Hevratit ve-ha-Irgunit 20-26; Rozen M., The Jewish Community of Jerusalem in the Seventeenth Century (Tel Aviv: 1984) 191-192 (Heb.); Hacker J.R., "Communal Organization among the Jewish communities of the Ottoman Empire (1453-1676)", in Grossman A. - Kaplan Y. (eds.), Kehal Yisrael:Jewish Self-Rule Through the Ages (Jerusalem: 1980) vol. 2, 301-303 (Heb.); Ben-Naeh, Jews in the Realm of the Sultans 218-221; Ben-Naeh Y., "Hibat Șiyon 'al ha-Bosphorus", Et-Mol 176 (2004) 28-29 (Heb.); Ben-Naeh Y., "Alliyah of a Grandee from Istanbul: Ya'akov Elnekave in Jerusalem", Cathedra 144 (2012) 21-34 (Heb.). The phenomenon is well documented in the Responsa literature; see, for example, R. Samuel de Medina, She'elot u-Teshuvot, I, (Salonica, Joseph Abraham Bathsheba: 1594), Yoreh de'ah §99. 
bestowed upon the community, while others remained under completely private ownership and were rented to the community.

The main reason for this phenomenon was the policy of local Muslim rulers. In the first decades of the Ottoman conquest, the rulers gave relative religious freedom to their Christian and Jewish subjects. The authorities did not damage their houses of worship and gave them permission to build new ones. But in the time of Sultan Bayezid II (1481-1512), the situation changed dramatically. It was forbidden to build new churches and synagogues, and those built in the time of Sultan Mehmed II (1444-1446, 1451-1481) were closed. ${ }^{13}$ They were opened again only in the period of Sultan Selim (1512-1520).

After the reign of Bayezid, conditions improved, but it was still prohibited to establish new synagogues. The Sultans adopted the Shar'i law which permitted non-Muslims to keep those houses of worship which had preceded the Muslim conquest, but prohibited the building of new ones. For example, in October 1540 Sultan Suleiman I (1520-1566) sent an order to the governor of Damascus, which prohibited the building of new synagogues but gave permission to the 'old' synagogues to continue their activities. ${ }^{14}$ In November 1584 another order was sent from the palace in Istanbul to the governor of Damascus, citing a complaint of the Qadi (Muslim judge) of Safed (in Galilee). The Qadi claimed that the Jews in his city had built new synagogues, and the Sultan ordered the governor to investigate the matter. ${ }^{15}$

During the Ottoman period public synagogues were subjected to constant danger. When it was discovered that a synagogue was not as old as the Jews claimed, the synagogue was then damaged by the authorities. For example, an old synagogue in Cairo was closed in $1545,{ }^{16}$ and a synagogue in Jerusalem was also closed in $1588 .{ }^{17}$ Some synagogues were demolished, such as the old

13 On the policy of Sultan Bayezid II towards the Jews and its implications on the synagogues, see Epstein M.A., The Ottoman Jewish Communities and their Role in the Fifteenth and Sixteenth Centuries (Freiburg: 1980), 29-31, 50; Hacker J.R., "The Background and the Implications of Avraham Ben Eliezer Ha-Levi's 'Megilat Setarim', Shalem 8 (2008) 471-473 (Heb.).

14 Cohen A. - Simon-Pikali E., Jews in the Moslem Religious Court: Society, Economy and Communal Organization in the XVIth Century, Documents from Ottoman Jerusalem (Jerusalem: 1993) 73-74 (Heb.).

15 Heyd U., Ottoman Documents on Palestine 1552-1615: A Study of the Firman according to the Mühimme Defteri (Oxford: 1960) 169.

16 Shtober S. (ed.), Sefer Divrey Yosef by Yosef ben Yitzhak Sambari: Eleven Hundred Years of Jewish History Under Muslim Rule (Jerusalem: 1994) 412-414 (Heb.).

17 Heyd, Ottoman Documents on Palestine 167-169; Cohen - Simon-Pikali,Jews in the Moslem Religious Court 70-88. The synagogue suffered harassment also in the Mamluk period, 
synagogue of Damascus, which was destroyed in $155^{2} .{ }^{18}$ Others were expropriated and became mosques.

This juridical condition remained without change until the middle of the nineteenth century, when the Ottomans started to make deep reforms in the administration and in the law. Those reforms, known as Tanzimat, gave equal rights to Christian and Jewish subjects of the Ottoman Empire, and as a result, allowed them to build houses of worship.

\section{$3 \quad$ Strategies for Coping with the Rules}

How did the Jews cope with the intolerance of the governors towards their prayer houses? A responsum of R. Jacob ibn Habib (d. 1516), an exile from Spain who settled in Salonica and is known as the author of 'En Ya'aqov, (an anthology of the Talmud's legends), gives us important information on the Jewish reaction to this policy. Ibn Habib described that in the beginning of the sixteenth century:

The synagogues where we are praying in the Turkish kingdom are inside the yards [...] Our residence in their houses and yards is temporary [...] In this time, under this kingdom, we have no permission to dedicate a house permanently for a synagogue, and all the more, so we do not have permission to build one. We need to hide ourselves under the ground, and 'her voice could not be heard' (I Samuel 1:13) because of the danger. Therefore, even if there is a residential house above the house of prayer, there is no need to protest about it, just to keep the house above clean. ${ }^{19}$

In this source, Ibn Habib describes two strategies the Ottoman Jews used in order to hide their places of prayer from the authorities: building a synagogue underground, and locating it in a private residence.

Immigrants were particularly affected by the legal restrictions on building new synagogues. While native Jews had their old synagogues, the immigrants

and in 1474 was demolished; see Little D.P., "Communal Strife in Late Mamlūk Jerusalem", Islamic Law and Society 6, 1 (1999) 69-96, esp. 78-87.

18 Avishur Y., "A Judeo Arabic Elegy on the Destruction of the Synagogue and the Riots in the Jewish Community of Damascus, 1553", Ben 'Ever La-'Arav 4 (2008) 98-104 (Heb.); Arad D., "Destruction and Memory: The Destruction of the Synagogue in Damascus and its Shaping of its remembrance in the Collective Memory", Zion 81 (2016) 67-94 (Heb.).

19 Cited in R.Joseph Caro, Bet Yoseph, on Tur Orah Hayim (Venice, Marco Antonio Giustiniani: 1550) §154; Hacker, Avraham Ben Eliezer Ha-Levi's 'Megilat Setarim' 472. 
did not have buildings for their public prayers and lacked the permission to build new synagogues.

The different Jewish groups in the Ottoman Empire had different liturgical customs. The immigrants wanted to keep their liturgical tradition and therefore preferred to establish new synagogues, rather than joining an existing local one. Their synagogue functioned for them, not only as an institution for preserving their old tradition, but also as a framework for self-determination. It was a place for meeting other Jews from their place of origin, and the main arena for the processes of social bonding between the immigrants. However, there were also synagogues in private homes among the native Jews. The growth of the population necessitated the construction of new synagogues for the natives as well, and some of these new prayer spaces were established in private homes.

Although the main reason for conducting public prayer in private houses was the legal reason (the ban on the construction of newer synagogues), there was also an economic reason for housing a synagogue in a private home. Building a new house, or renting one, and maintaining its activity was a heavy burden on the treasury of the Qahal. An easy solution was to arrange the prayers in a private house.

A combination of several factors therefore contributed to the high number of private houses which functioned as prayer spaces among the Ottoman Jews.

\section{Private Synagogues and the Muslim Authorities}

Despite the financial difficulty described above, in some cases the Qahal succeeded in raising enough money to construct a new building for prayer. This step was dangerous. These new synagogues never got official approval from the authorities and their existence, as mentioned above, was under continuous threat. This instability is portrayed in a case from Istanbul in the sixteenth century. The Cordova Qahal, that is to say the community of immigrants from Cordova in the Ottoman capital, rented land and built a synagogue. A conflict then arose about the ownership, which was brought before the Muslim court. One of the litigants told the Qadi that the Jews had built a synagogue on that land, and the Judge 'boiled with anger and said':

'Who is he that dared to do so?!,20 and said this house must be destroyed. Immediately the people of the Qahal were galvanized and cleared out 
the synagogue and took out all the Torah scrolls and the (oil) lamps, and they redesigned the space as a residence, and did not go to pray there for a long time. ${ }^{21}$

A similar case occurred in Jerusalem. The Jews established a prayer site in a private apartment and were subjected to threats and extortion. They sent a messenger to the Sultan's palace in Istanbul to lobby him in order to defend the new synagogue and as a result, in December 1581, Sultan Murad III (1574-1595) wrote a letter to the Qadi of Jerusalem and commanded him as follows:

To the Qadi of Jerusalem: The Jews of Jerusalem recently sent a man to my exalted gate and announced: According to our ritual, we gathered in one house, we worshiped God and read the Torah [...] Some people decided to hurt us and to harass us, with no reason, just to steal money and attain benefits. I command that when my decree arrives, you should check [the matter] [...] If there are no pictures and no Mihrā $b^{22}$ in that house, and if when they worship God they do not read the Torah loudly, and nevertheless people hurt them and harass them, in contrast to the Shari ${ }^{-} a$, in order to steal money and gain benefit - stop it, and do not enable anybody to behave in contrast to the noble Sharia. Castigate those who do not obey, and send their names to me. ${ }^{23}$

The scribe used Muslim terminology here. Mihrāa is a semi-circular niche in the front of the mosque that indicates the Qibla; that is to say, the direction in which the community faces while praying. There is no doubt that the scribe was referring to the ark of the synagogue, which is also located in front of the

21 R. Elijah b. Hayim, Heleq Rishon mi-Teshuvot She'elot (Istanbul, unknown printer: circa 1610) §6o, p. 93c. The title page of the book lacks a date and the name of the printer. Following the reference to 'in the city of the great king Sultan Ahmed' (הקרית המלך), באדיר שולטאן אחמיט), researchers dated it to the reign of Ahmed I (1603-1617). The date here (circa 1610) is according to the record in the Bibliography of the Hebrew Book of the National Library of Israel. The reliability of the place's record on the title page was a source of controversy among scholars; see Heller M.J., The Seventeenth Century Hebrew Book: An Abridged Thesaurus (Leiden - Boston 2011) vol. 1, 123.

I preferred to keep the original Arabic term in my translation (the text itself was written in Turkish). In their Hebrew translation, the editors used the Hebrew term Mizrah (literally: 'east'), which indicates the direction of the Jewish Prayer. The term is Ashkenazic and reflects the fact that in Central/East European Jews' eyes the Land of Israel was located in the east (even though it is actually southeast of Europe).

Cohen - Simon-Pikali, Jews in the Moslem Religious Court 79-8o (my translation). 
worshippers. Indeed, in some synagogues in Muslim countries, the ark was influenced in its design by the Muslim Mihrāa .

According to Jewish law, a synagogue is a holy place and has many restrictions (it is forbidden to eat or sleep inside it; it may be sold only under certain conditions, etc.). There is no need of a certain object, or a certain design, in order to define it as a synagogue. The only conditions are the intention to use the space as a synagogue, and the inauguration of the space as a prayer space by ten men. ${ }^{24}$

However, the Muslim authorities were bothered mainly by the physical appearance of the synagogue. The cases discussed above, in Jerusalem and Istanbul, reflect the fact that the policy against new synagogues was focused on the question of visibility. A building was considered a synagogue if it contained the typical elements of classic synagogues: Torah ark, parokhot (curtains for covering the ark), a bimah (the podium from which the Torah is read), oil lamps hanging from the ceiling, etc.

The establishment of small synagogues inside private houses was a means of circumventing the Islamic law prohibiting the building of synagogues. The sultans wanted to give their Jewish subjects (as well as their Christians subjects) a certain degree of religious freedom, but did not desire a confrontation with the 'Ulam $\bar{a}$, the Muslim sages, who criticized the sultans' tolerance towards non-Muslims. ${ }^{25} \mathrm{~A}$ hidden synagogue, in a private house, which did not bear any standard religious symbols, was something that the sultans could live with.

This unique situation of public prayers in private homes sometimes provoked conflicts between the homeowner and the worshippers. The conflicts were caused by several issues, including rental fees, the demand for special rights for the owner's family, and the appointment of trustees among the worshippers. For example, for a while the synagogue of the North-African Jews in Cairo was located in a house that belonged to a widow called Najma. Initially, she rented one of the rooms to the Qahal for prayer, but later, she sold part of the

24 R. Joseph Karo, Shulhan 'Arukh (Venice, Meir Parenzo and Aluise Bragadin: 1564), Orah Hayim, $\S 153,8$.

25 The tolerant policy of the Sultans, as shown by Karen Barkey, was caused by their desire to build their image as protectors of the non-Muslim minorities and thereby to strengthen the stability of their kingdom; see Barkey K., Empire of Difference: The Ottomans in Comparative Perspective (Cambridge: 2008). 
space to the community, while another space remained rented. An anonymous questioner described the situation to Rabbi David ibn Zimra (d. 1572/3), the famous Sephardic sage: ${ }^{26}$

Rachel ${ }^{27}$ has a house which was rented to the Qahal for several years for prayer. Then she had financial problems and sold a quarter of the house to the Qahal. Because of the [large] number of worshippers, it was necessary to break walls in the house and to build and repair it, in order to expand it. They appeased her with some (amount of money) until she gave permission to break and rebuild. ${ }^{28}$

Additional information about this incident can be found in the Cairo Genizah. A court deed with the agreement between the two sides about this renovation resides in the Cambridge Genizah collection, ${ }^{29}$ and it sheds light on the renovation and on the history of the Maghribian immigrants in Egypt in the Early Ottoman period..$^{30}$ However, after the renovation, Najma wanted to raise the rental fees, but the representatives of the Qahal refused and said that since they had paid the renovations from their own funds, Najma had no right to raise the rent. The litigants went to the court of R. David ibn Zimra, who accepted the Qahal's argument.

Conflicts over financial affairs in private synagogues were the simplest type of problem. More problematic were conflicts over control, which had the potential to destroy the Qahal completely.

Private ownership of a synagogue gave a great deal of power - too great - to the owner. The community of worshippers was dependent on the good will of the homeowner, and could suffer as a result of his/her whims. For instance, Rabbi Moses of Trani discussed the case of a man from an unidentified city who dedicated a house in his ownership to the construction of a synagogue, but later decided to convert. After his conversion, he returned and expropriated

26 On Ibn Zimra, see Zimmels H.J., Rabbi David Ibn Abi Simra (Breslau: 1932); Goldman, Rabbi David Ibn Abi Zimra.

27 Her name actually was Najma (in Arabic: a star), as mentioned above, but in the Responsa literature it is very common to give the person a generic name, like Reuben and Simon for men, and Rachel and Leah for women.

28 R. David Ibn Zimra, Shut ha-Radbaz (Warsaw: 1882) I, §146, $102 a$.

29 MS Cambridge, T-S 13 J 37.1. Published by Arad D., "Cairo's Maghribians and Musta'ribs: From Close Cooperation to Conflict and Estrangement", in Ben-Naeh Y. - Idel M. - Cohen J. - Kaplan Y. (eds.), Studies in Jewish History Presented to Joseph Hacker (Jerusalem: 2014) 482-485 (Heb.).

Arad, "Cairo's Maghribians and Musta'ribs" 470-479. 
the synagogue from its use by the worshippers, although he was willing to sell it to them. ${ }^{31}$

Conducting communal religious life in private homes weakened the power of the leadership of the Qahal. A synagogue under private ownership had two competing centres of power: the leaders of the community and the owner of the home. For example, in a private synagogue in Salonica, the leadership of the community decided to publish rules concerning communal taxes. Every Jewish community in the Ottoman Empire had a set of communal rules [in Hebrew: Haskamot] that covered cases which were not dealt with in Jewish religious legal texts. The majority of the community agreed to accept these new rules, but a minority rejected them. The landlord, who was among the minority, declared:

If you don't want to accept my opinion, go out of my synagogue. And he did so many times, when a person or even many people from the Qahal disagreed with him. ${ }^{32}$

As a result, the majority decided to leave the synagogue and establish a new synagogue under common ownership. The majority also wanted to take all the holy objects which were kept in the private synagogue and which had been donated by the worshippers with them to their new synagogue. The owner of the building argued that communal rules forbade dividing the Qahal, and that people who left the synagogue had no right to the holy objects. The question was discussed by several noted scholars, including Rabbi David ibn Zimra of Cairo. Ibn Zimra thought that the people who left the synagogue were entitled to leave and to take all the objects with them. He concluded:

They will be blessed, because they will pray now in a place belonging to the public, giving everyone an equal right, and not in a place that belongs to an individual. ${ }^{33}$

Ibn Zimra therefore gave priority to the public synagogue, which belonged equally to each member of the community, rather than to a private synagogue. Nevertheless, private synagogues became more and more widespread during the sixteenth century and even more so during the seventeenth century.

31 R. Moses Trani, She'elot u-Teshuvot, I, (Venice, Pietro, Aluise and Lorenzo Bragadin: 1629) §214.

32 Ibn Zimra, Shut ha-Radbaz, I, §292, 46a-46b.

33 Ibid. 
Conducting public prayers in private homes became a factor that weakened, rather than strengthened, the power of the community. It preserved power in the hands of a small number of people - the rich men who had the money that enabled them to hold the synagogues in their homes - and disturbed the effort to build an equal and democratic community.

During the seventeenth century, the framework of the Qahal based on a common origin of immigrants became weaker and weaker. New social frameworks appeared in Jewish society, including social organizations, guilds and urban associations. ${ }^{34}$ The framework of the Qahal was very useful in the first generations after the great migration to the Empire, but later lost its power and finally disappeared. Conflicts about control in synagogues and other places, however, have remained with us up to the present day.

\section{Bibliography}

Arad D., "Cairo's Maghribians and Musta'ribs: From Close Cooperation to Conflict and Estrangement", in Ben-Naeh Y. - Idel M. - Cohen J. - Kaplan Y. (eds.), Studies in Jewish History Presented to Joseph Hacker (Jerusalem: 2014) 443-486 (Heb.).

Arad D., "Destruction and Memory: The Destruction of the Synagogue in Damascus and its Shaping of its remembrance in the Collective Memory", Zion 81 (2016) 67-94 (Heb.).

Arad D., "Welfare and Charity in a Sixteenth-Century Jewish Community in Egypt: A Study of Genizah Documents", Al-Masāq:Journal of the Medieval Mediterranean 29 (2017) $25^{8-272 .}$

Barkey K., Empire of Difference: The Ottomans in Comparative Perspective (Cambridge: 2008).

Beinart H. (ed.), Moreshet Sepharad: The Sephardi Legacy (Jerusalem: 1992).

Benbassa E. - Rodrigue A., Juifs des Balkans: Espaces judéo-ibériques, XIVe-XXe siècles (Paris: 1993).

Ben-Naeh Y., "Jewish Confraternities in the Ottoman Empire in the 17th and 18th centuries", Zion 63 (1998) 277-318 (Heb.).

Ben-Naeh Y., Jews in the Realm of the Sultans: Ottoman Jewish Society in the Seventeenth Century (Tübingen: 2008).

Berav Jacob, She'elot u-Teshuvot (Venice, Andrea Morisoni: 1663).

34 See Ben-Naeh Y., "Jewish Confraternities in the Ottoman Empire in the seventeenth and eighteenth centuries", Zion 63 (1998) 277-318 (Heb.). 
Bowman S.B., "Survival in Decline: Romaniote Jewry post-1204", in Bonfil R. Irshai O. - Stroumsa G.G. - Talgam R. (eds.), Jews in Byzantium: Dialectics of Minority and Majority Cultures (Leiden - Boston: 2012) 101-132.

Braude B. - Lewis B. (eds.), Christians and Jews in the Ottoman Empire: The Functioning of a Plural Society (New York: 1982).

Cassuto D., "Synagogues in the Islamic World", in Stillman N.A. (ed.), Encyclopedia of Jews in the Islamic World, 5 vols. (Leiden - Boston: 2010), IV, 423-432.

Cohen A., A World Within: Jewish Life as Reflected in Muslim Court Documents from the Sijill of Jerusalem (XVIth Century), I (Texts) - II (Facsimiles) (Philadelphia: 1994).

Cohen A., Jewish Life under Islam: Jerusalem in the Sixteenth Century (Cambridge, Mass.: 1984).

Cohen A. - Simon-Pikali E., Jews in the Moslem Religious Court: Society, Economy and Communal Organization in the XVIth Century, Documents from Ottoman Jerusalem (Jerusalem: 1993) (Heb.).

De Medina Samuel, She'elot u-Teshuvot, 3 vols. (Salonica, Joseph Abraham Bathsheba: 1594-1597).

Epstein M.A., The Ottoman Jewish Communities and their Role in the Fifteenth and Sixteenth Centuries (Freiburg: 1980).

Fargeon M., Les juifs en Egypte: depuis les origines jusqu'à ce jour (Cairo: 1938).

Gerber H., Crossing Borders: Jews and Muslims in Ottoman Law, Economy and Society (Istanbul: 2008).

Goldman I.M., The Life and Times of Rabbi David Ibn Abi Zimra (New York: 1970).

Gottheil R.J.H., "Dhimmis and Muslems in Egypt", in Harper R.F. - Brown F. Moore G.F. (eds.), Old Testament and Semitic Studies in Memory of William Rainey Harper, 2 vols. (Chicago: 1908) vol. 2, 351-414.

Ha-Levi Jacob, She'elot u-Teshuvot (Venice, Giovanni Caleoni: 1614-1615).

Ha-Levi Mordechai, Darke No'am: She'elot u-Teshuvot (Venice, Vincenzo and Aluise Bragadin: 1697).

Heller M.J., The Seventeenth Century Hebrew Book: An Abridged Thesaurus (Leiden Boston: 2011).

Heller M.J., The Sixteenth Century Hebrew Book: An Abridged Thesaurus (Leiden Boston: 2003).

Heyd U., Ottoman Documents on Palestine 1552-1615: A Study of the Firman according to the Mühimme Defteri (Oxford: 1960).

Heyd U., "Turkish Documents Concerning the Jews of Safed in the Sixteenth Century", in Ma'oz M. (ed.), Studies on Palestine during the Ottoman Period (Jerusalem: 1975) 111-118.

Hollender E., "Mahzor Romania and the Judeo-Greek Hymn éva o o xup Critical Edition, and Commentary", Revue des Études Juives 170 (2011) 117-171. 
Ibn Habib Levi, She'elot u-Teshuvot (Venice, s.n.: 1565).

Ibn Hayim Elijah, Heleq Rishon mi-Teshuvot She'elot (Istanbul, s.n.: circa 1610).

Ibn Zimra D., Shut ha-Radbaz, 7 vols. (Warsaw - Iuzefov: 1882).

Juhasz E., "Synagogues", in Juhasz E. (ed.), Sefardi Jews in the Ottoman Empire: Aspects of Material Culture (Jerusalem: 1990) 36-59.

Levy A. (ed.), Jews, Turks, Ottomans (Syracuse: 2002).

Levy A., The Sephardim in the Ottoman Empire (Princeton: 1992).

Millgram A.E., Jewish Worship (Philadelphia: 1971).

Mizrahi Elijah, Teshuvot She'elot (Istanbul, Solomon Jabez: 1559-1561).

Reif S.C., Judaism and Hebrew Prayer (Cambridge: 1993).

Rozen M., A History of the Jewish Community in Istanbul: The Formative Years, 1453-1566

(Leiden - Boston: 2002).

Shaw S.J., The Jews of the Ottoman Empire and the Turkish Republic (London: 1992).

Shmuelevitz A., The Jews of the Ottoman Empire in the Late Fifteenth and the Sixteenth Centuries: Administrative, Economic, Legal, and Social Relations as Reflected in the Responsa (Leiden: 1984).

Shtober S. (ed.), Sefer Divrey Yosef by Yosef ben Yitzhak Sambari: Eleven Hundred Years of Jewish History Under Muslim Rule (Jerusalem: 1994) (Heb.).

Tabory J., Jewish Prayer and the Yearly Cycle - A List of Articles [Kiryat Sefer 64, Supplement to Volume 64] (Jerusalem: 1992-1993).

Trani Moses, She'elot u-Teshuvot, 2 vols. (Venice, Pietro, Aluise and Lorenzo Bragadin: 1629-1630).

Weiker W.F., Ottomans, Turks, and the Jewish Polity: A History of the Jews of Turkey (Lanham: 1992). 